Bangladesh J. Bot. 42(1): 105-111, 2013 (June)

\title{
EFFECTS OF COPPER AND CHROMIUM AND HIGH TEMPERATURE ON GROWTH, PROLINE AND PROTEIN CONTENT IN WHEAT SEEDLINGS
}

\author{
Ahmet Muslu and Nuray Ergün* \\ Department of Biology, Faculty of Science and Art, Mustafa Kemal University, \\ Tayfur Sökmen Campus, 31034 Hatay, Turkey
}

Key words: Carotenoid, Chlorophyll, Chromium, Copper, Free proline, Soluble proteins, Temperature, Wheat

\begin{abstract}
Effects of interactions between high temperature and chromium $(\mathrm{Cr}(\mathrm{VI}))$ and copper $(\mathrm{Cu})$ on wheat (Triticum aestivum L. cv. Dagdas 94) seedlings were investigated. High concentrations of $\mathrm{Cr}$ and $\mathrm{Cu}$ at $40^{\circ} \mathrm{C}$ decreased the root and shoot length and dry weight. The total chlorophyll content was decreased at $30 \mu \mathrm{M} \mathrm{Cr}$ $+40^{\circ} \mathrm{C}$. At the high $\mathrm{Cr}$ and $\mathrm{Cu}$ concentrations, carotenoid content was increased compared to that of control groups. Heavy metal treatment increased proline content but decreased that of soluble protein. In addition, chromium showed greater toxic effects on growth and biochemical parameters than that of $\mathrm{Cu}$.
\end{abstract}

\section{Introduction}

Numerous abiotic stress factors such as high temperature, drought, salinity, chemical toxicity, and oxidative stress severely threaten agriculture throughout the world (Wang et al. 2003). Abiotic stresses may lead to a yield loss exceeding $50 \%$ in plants, and are the main cause of agricultural crop losses world-wide (Bray et al. 2000). Increased heavy metal pollution of the soil is another important abiotic stress factor that threatens human health and the fertility of agricultural land. Metals such as lead $(\mathrm{Pb})$, cadmium $(\mathrm{Cd})$, chromium $(\mathrm{Cr})$, and copper $(\mathrm{Cu})$ may inhibit certain essential physiological activities (Foy et al. 1978). Pandey and Sharma (2003) showed that Cr treatment decreased the Fe concentration in cabbage leaves. High levels of $\mathrm{Cu}$ are also known to inhibit metabolic activities such as germination, root, leaf and stem growth and photosynthesis, biomass, and the pigment content (Foy et al. 1978, Pandley and Sharma 2003, Shanker et al. 2005, Mallick et al. 2010).

Organic compounds such as proline, glycine betaine and soluble carbohydrate accumulate to produce an osmotic effect, which can regulate the osmotic intensity of cellular fluids under stress conditions. Plant protein synthesis is also associated with stress tolerance mechanisms under various abiotic stress conditions, such as exposure to high temperature and heavy metals (Walters et al.1996, Rauser 1990).

In the present investigation, the effects of $\mathrm{Cr}$ and $\mathrm{Cu}$ on wheat seedlings and different temperatures on root and shoot length, dry weight, pigment, free proline and soluble protein contents are reported.

\section{Materials and Methods}

Wheat seeds (T. aestivum cv. Dagdas 94) were obtained from Adana Cukurova Agriculture Faculty. Seeds were germinated in Petri dishes under sterile conditions at a temperature of $24 \pm$ $2^{\circ} \mathrm{C}$ for $48 \mathrm{hrs}$, before being transferred to pots containing a mixture of sand and perlite $(1: 1, \mathrm{v}$ : $\mathrm{v})$, which were irrigated with distilled water. The pots were kept in climate cabinet conditions for five days to allow the seedlings to grow with $24 \mathrm{hrs}$ ventilation. At the end of this period, the

*Author for correspondence: <ergun.nuray@gmail.com>. 
seedlings were transferred into full strength Hoagland solution (Arnon and Hoagland 1950) and grown for a further 5 days in the same climate cabinet conditions (60\% relative humidity; $24 \pm$ $2^{\circ} \mathrm{C} ; 12: 12 \mathrm{hrs}$, day : night). The nutrient solution was replaced after a further 5 days.

The experiment was conducted at two different temperatures. In the first experiment 10-dayold plants were grown separately in nutrient solutions containing chromium $\left(\mathrm{K}_{2} \mathrm{Cr}_{2} \mathrm{O}_{7}\right)$ or copper $\left(\mathrm{CuSO}_{4} \cdot 5 \mathrm{H}_{2} \mathrm{O}\right)$ at a temperature of $24 / 16^{\circ} \mathrm{C}$ (day/night). $\mathrm{Cr}$ or $\mathrm{Cu}$ was dissolved in the Hoagland solution at concentrations of 10 and $30 \mu \mathrm{M}$. Control groups were grown with only Hoagland solution. In the second experiment, the same applications were repeated until the fourth day without any change in the initial conditions. At the end of the fourth day of heavy metal application, the cabinet temperature was increased from $24 / 16^{\circ} \mathrm{C}$ to $40 / 30^{\circ} \mathrm{C}$ (day/night), and the plants were exposed to this high temperature stress for $24 \mathrm{hrs}$. The seedlings were harvested after the fifth day of the heavy metal treatment. Each experiment was repeated three times.

The 15-day-old seedlings, which received temperature and heavy metal treatments, were harvested and the lengths of the root and shoot were measured. The samples were dried in an oven at $110^{\circ} \mathrm{C}$ for $24 \mathrm{hrs}$ and dry root and shoot weights were recorded.

Chlorophyll was extracted by homogenizing fresh leaf material with $10 \mathrm{ml}$ of $80 \%$ acetone and filtered. Chlorophyll, total chlorophyll, the chlorophyll a/b ratio, and the carotenoid contents were determined according to the method of Arnon (1949). These values were then corrected according to the method of Porra (2002).

Free proline was determinated in fresh material according to the Bates et al. (1973). Soluble protein was extracted from the fresh material (Jordan et al. 1992) and its level was determined after Lowry et al. (1951).

Analysis of variance (ANOVA) was used to compare the weights obtained at the end of the experiment. If a statistical difference was found in the groups compared by ANOVA, a multiple comparison method for different groups was used, i.e., Duncan's test.

\section{Results and Discussion}

The application of 10 or $30 \mu \mathrm{M} \mathrm{Cr}$ and $30 \mu \mathrm{M} \mathrm{Cu}$ at high temperature produced a lower root dry weight and root length in wheat seedlings compared to that of the control. In contrast to $\mathrm{Cr}, \mathrm{Cu}$ had no effect at $24^{\circ} \mathrm{C}$ (Table 1). Shanker et al. (2005) demonstrated that inhibition of root cell growth reduced plant growth by impairing mineral and water transport to the plant. Mallick et al. (2010) found that $\mathrm{Cr}$ inhibited the root length more than the shoot of Zea mays seedlings because it accumulated in the roots.

The total chlorophyll content was not significantly affected by heavy metal treatment, whereas a high temperature - $\mathrm{Cr}$ interaction decreased the total chlorophyll content (Fig. 1). High temperature treatment with $10 / 30 \mu \mathrm{M} \mathrm{Cr}$ or $10 \mu \mathrm{M}$ Cu increased the chlorophyll a/b ratio in wheat seedlings (Fig. 2). The reduced chlorophyll content with heavy metal stress was probably the result of heavy metals blocking the enzymes involved in the chlorophyll biosynthesis pathway. They indicated that plants raised under high $\mathrm{Cu}$ concentration, chlorophyll quantitiy decreased parallel to the decrease of iron (Fe).

The chlorophyll a/b ratio was significantly affected by $\mathrm{Cu}$ application (Fig. 2). Vernay et al. (2007) showed that the chlorophyll $a / b$ ratio decreased significantly as a result of $100 \mu \mathrm{M} \mathrm{Cr}$ treatment. This is because the $\mathrm{Cr}$ treatment affected chlorophyll $a$ more than chlorophyll $b$. Cr (VI) $(0.10,0.15$, and $0.25 \mathrm{mM})$ treatments of $T$. aestivum seedlings led to a lower amount of chlorophyll $a$ and $b$ (Subrahmanyam 2008). 


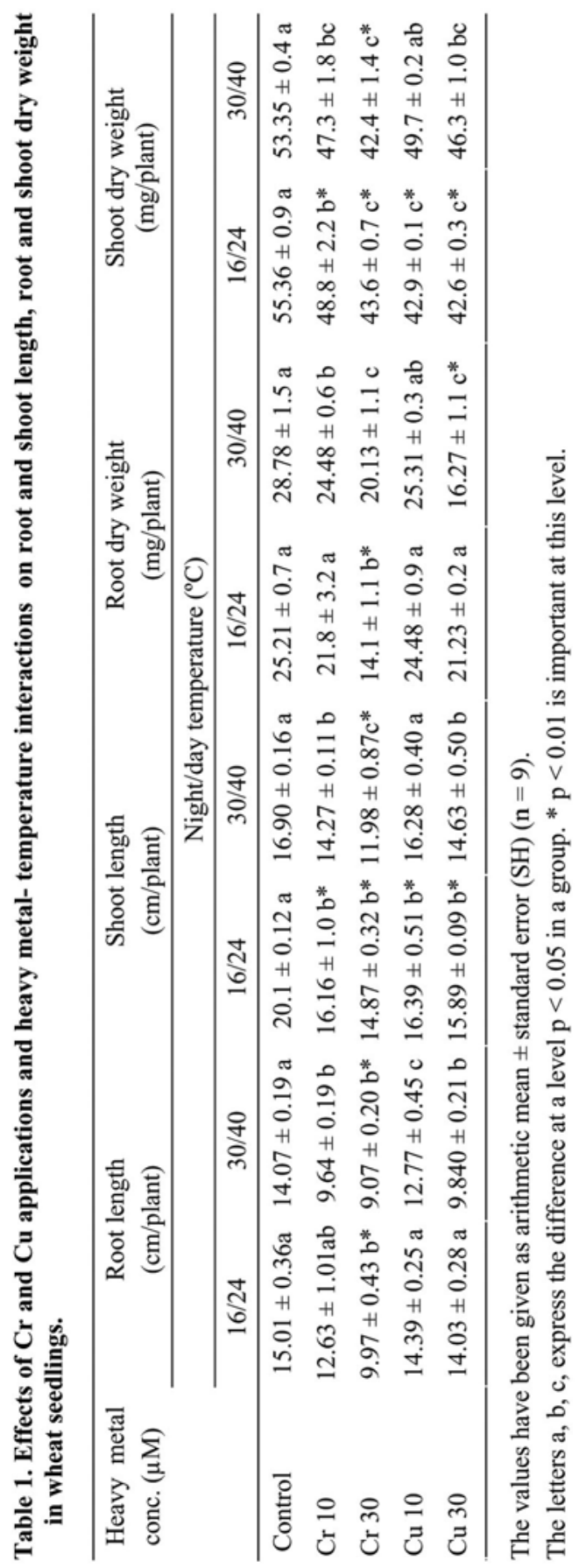


Carotenoid content was increased following the application of both heavy metals at a high temperature. However, 10 and $30 \mu \mathrm{M} \mathrm{Cu}$ treatments at $24^{\circ} \mathrm{C}$ decreased the carotenoid content of wheat seedlings (Fig. 3).

Lipids are essential for photosynthetic activity under conditions of environmental stress and the breakdown of lipids by high light and/or temperature may reduce photosynthesis (Mishra and Singhal 1992).

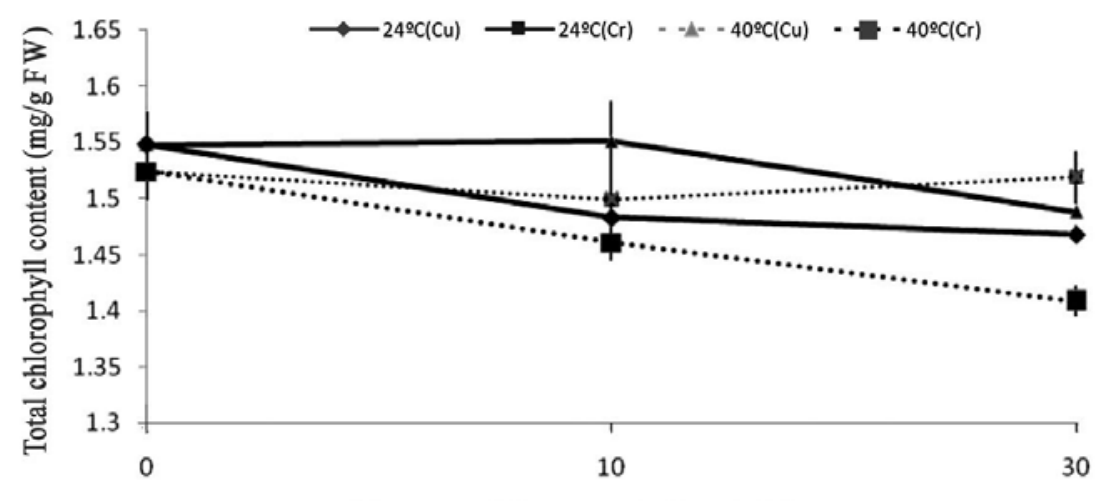

Heavy metal concentration $(\mu \mathrm{M})$

Fig. 1. The effect $\mathrm{Cr}$ and $\mathrm{Cu}$ and heavy metal-temperature interaction on the total chlorophyll content in wheat seedlings $(n=9)$.

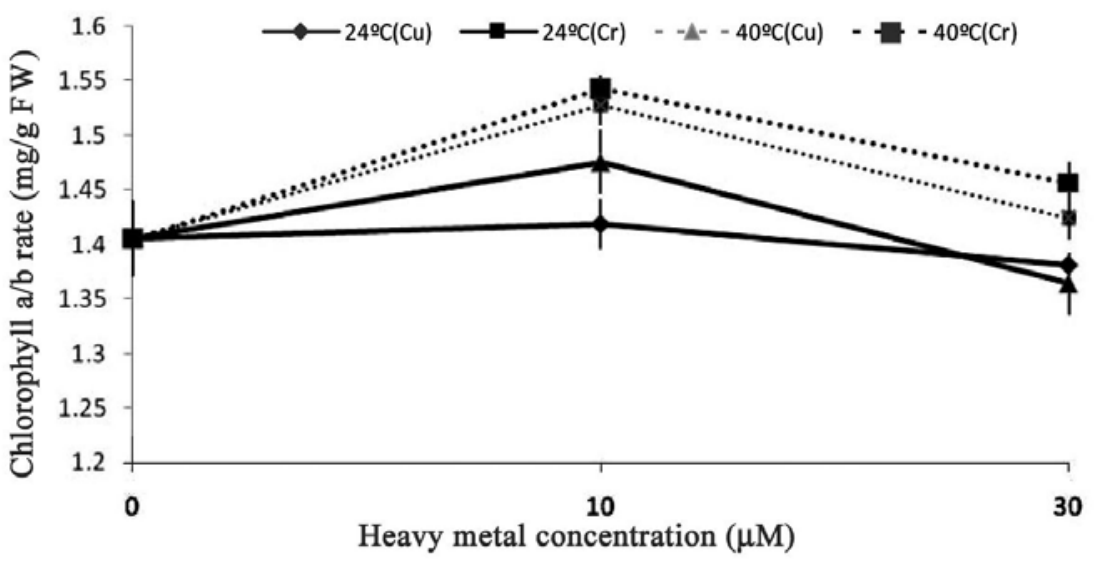

Fig. 2. The effect of $\mathrm{Cr}$ and $\mathrm{Cu}$ and heavy metal-temperature interaction on chlorophyll $a / b$ rate in wheat seedlings $(n=9)$.

The free proline content of wheat seedlings was not significantly affected by $\mathrm{Cu}$ applications at $24^{\circ} \mathrm{C}$, although $\mathrm{Cu}$ had a significant effect at high temperature. Chromium stimulated proline accumulation following low and high temperature treatments (Fig. 4). Substantial increase was reported in the proline content of leaves of wheat with increasing heavy metal concentrations (Panda et al. 2003). 


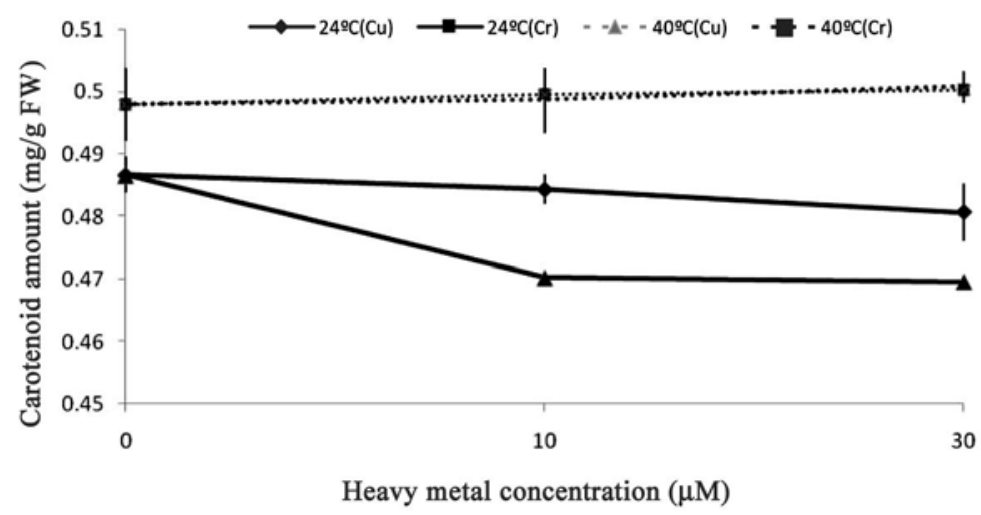

Fig. 3. The effect of $\mathrm{Cr}$ and $\mathrm{Cu}$ and heavy metal-temperature interaction on carotenoid content in wheat seedlings $(\mathrm{n}=9)$.

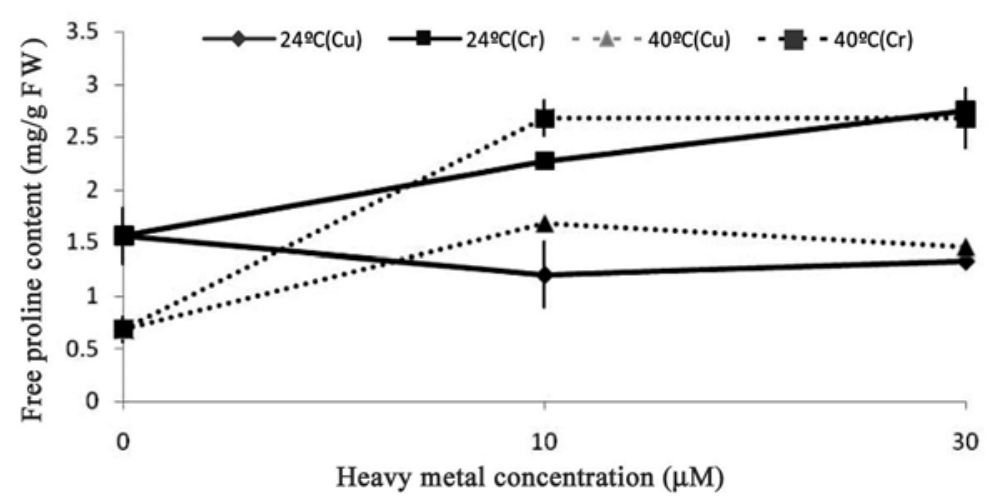

Fig. 4. The effect of $\mathrm{Cr}$ and $\mathrm{Cu}$ and heavy metal-temperature interaction on free proline content in wheat seedling $(\mathrm{n}=9)$.

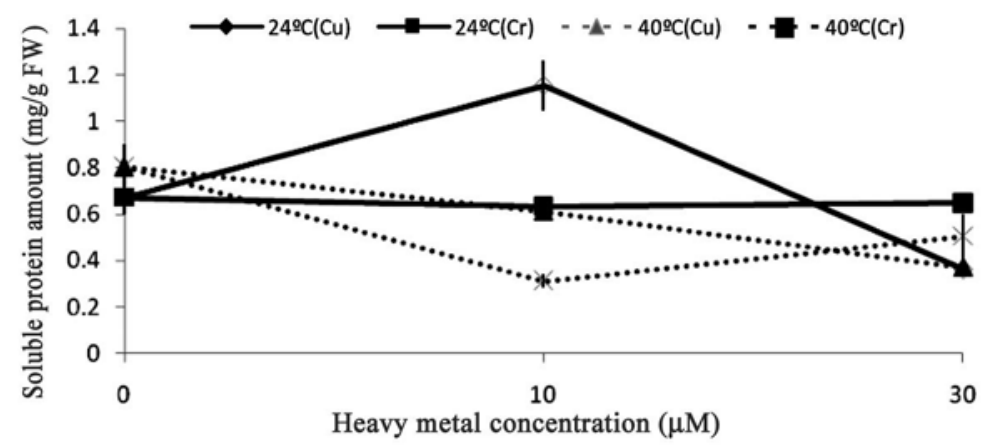

Fig. 5. The effect of $\mathrm{Cr}$ and $\mathrm{Cu}$ and heavy metal-temperature application on soluble protein content in wheat seedlings $(n=9)$.

$10 \mu \mathrm{M} \mathrm{Cu}$ at $24^{\circ} \mathrm{C}$ increased the soluble protein content, but it decreased that at $30 \mu \mathrm{M} \mathrm{Cu}$ concentration. $\mathrm{Cr}$ at $24^{\circ} \mathrm{C}$ did not cause a significant change in the soluble protein content. The application of both heavy metals at high temperature led to a lower soluble protein content (Fig. 5). The significant reduction in the soluble protein concentration with the $30 \mu \mathrm{M} \mathrm{Cu}$ treatment at 
24 and $40^{\circ} \mathrm{C}$ may be because protein was not synthesised under stress conditions and/or existing proteins were broken down into amino acids (Levitt 1972). The synthesis of new proteins by plants during stress conditions may be a defence mechanism that compensates for the breakdown of existing proteins into amino acids (Levitt 1972).

It is suggested that conventional and molecular improvements should be combined to develop cross-tolerances, such as temperature-heavy metal stress tolerance in agricultural plants.

\section{Acknowledgements}

The present paper is a part of the M.Sc. thesis of the first author (AM) which is supported by Mustafa Kemal University Scientific Project Department. Project number: 04 -Y0103.

\section{References}

Arnon DI 1949. Copper enzymes in isolated chloroplasts Polyphanoloxidase in Beta vulgaris. Plant Physiol. 24: 1-15.

Bates LS, Walderen RD and Taere ID 1973. Rapid determination of free proline for water stress studies. Plant Soil 39: 205-207.

Bray EA, Bailey-Serres J and Weretilnyk E 2000. Responses to abiotic stresses. In: Buchanan B, Dunwell JM 2000. Transgenic Approaches to Crop Improvement, J. Exp. Bot. 51: 487-496.

Foy CD, Chaney PL and White MC. 1978. The physiology of metal toxicity in plants. Ann. Rev. Plant Physiol. 29: 551-566.

Arnon DI and Hoagland DR 1940. Crop production in artificial solutions and in soils with special reference to factors influencing yields and absorbtion of inorganic nutrients In: F.C. Steward Plant Physiol A Treatise. Vol: 3, Academic Press, New York, London, 1963.

Jordan BR, He J, Chow WS and Anderson JM 1992. Changes in mRNA levels and peptide subunits of ribulose-1.5-bisphosphate carboxylase in response to supplementary ultraviolet-B radiation. Plant Cell and Environ. 15: 91-98.

Levitt J 1972. Responses of Plants to Environmental Stresses. Academic Press. New York.

Lowry OH, Rosebrough NJ, Farr AL and Randall RJ 1951. Protein measurement with the folin phenol reagent. J. Bio. Chem. 193: 265-275.

Mallick S, Sinam G, Mishra RK and Sinha S 2010. Interactive effects of Cr and Fe treatments on plants growth, nutrition and oxidative status in Zea mays L. Ecotoxicology and Environ. Safety 73: 987-995.

Mishra RK and Singhal GS 1992. Function of photosynthetic apparatus of intact wheat leaves under high light and heat stress and its relationship with peroxidation of thylakoid lipids. Plant Physiol. 98: 1-6.

Panda SK, Chaudhury I and Khan MH 2003. Heavy metals induce lipid peroxidation and effect antioxidants in wheat leaves. Biologia Plant. 46: 289-294.

Pandey N and Sharma CP 2003. Chromium interference in iron nutrition and water relations of cabbage. Environ. and Exp. Bot. 49: 195-200.

Porra RJ 2002. The chequered history of the development and use of simultaneous equations for the accurate determination of chlorophylls $a$ and $b$. Photosynthesis Research 73: 149-156.

Rauser WE 1990. Phytochelatins. Annu. Rev. Biochem. 59: 61-86.

Shanker AK, Cervantes C, Tavera HL and Avudainayagam S 2005. Chromium toxicity in plants. J. Environ. Int. 31: 739-753.

Subrahmanyam D 2008. Effects of chromium toxicity on leaf photosynthetic and oxidative changes in wheat (T. aestivum L.). Photosynthetica. 46: 339-345.

Vernay P, Gauthier-Moussard C and Hitmi A 2007. Interaction of bioaccumulation of heavy metal chromium with water relation, mineral nutrition and photosynthesis in developed leaves of Lolium perene $\mathrm{L}$. Chemosphere. 68:1563-1575. 
Wang WX, Vinocur B and Altman A 2003. Plant responses to drought, salinity and extreme temperatures: towards genetic engineering for stress tolerance. Planta 218: 1-14.

Wlaters ER, Lee GJ and Vierling E 1996. Evolution, structure and function of the small heat shock proteins in plants. J. Exp. Bot. 47: 325-338

(Manuscript received on 11 February, 2013; revised on 4 April, 2013) 